\title{
Impact of micro finance: perceptions of direct stakeholders of self help groups
}

\author{
Sanjay Kanti Das ${ }^{1, *}$, Amalesh Bhowal ${ }^{2}$ \\ ${ }^{1}$ Head, Department of Commerce, Lumding College, Lumding, Nagaon, Assam-782447, India \\ ${ }^{2}$ Dept. of Commerce, Assam University, Diphu Campus, Assam-782462, India
}

Email address:

sanjay19711123@rediffmail.com(S. K. Das),profabhowal@gmail.com(A. Bhowal)

\section{To cite this article:}

Sanjay Kanti Das, Amalesh Bhowal. Impact of Micro Finance: Perceptions of Direct Stakeholders of Self Help Groups. International Journal of Business and Economics Research. Vol. 2, No. 6, 2013, pp. 142-157. doi: 10.11648/j.ijber.20130206.14

\begin{abstract}
Self Help Group is a unique innovation of credit delivery technique and has produced positive impacts on two vital areas of national development, alleviation of poverty and women's empowerment. Sixty five variables relating to impact of SHGs on members are identified from survey of literature and relevant perception of direct stakeholders whether the aspects like impact on members of SHG and its involvement in larger social issues should be peripheral or core components of quality indicators of SHG is perceived in this study. The study is conducted by using multi-stage random sampling method to collect primary data from the selected Development Blocks of Nagaon districts of Assam (India). It is observed that there was no significant effect of stakeholders on overall score on impact on members of SHG as Peripheral or Core issue. It is observed that different stakeholders believed that the impact on members of SHG and its involvement in larger social issues should be 'somewhat core component' as the mean value lies in between the scale range of $1 \& 0$ which represents the range of 'somewhat core component'. It is further observed that Financial Institutions are less concerned about the social issues while Donor's are more concerned about the social issues.
\end{abstract}

Keywords: Assam, Core Component, Direct Stakeholders, Peripheral Components, Psychometrics, Impact on Members, Self Help Group

\section{Introduction}

The Millennium Development Goal (MDG) emphasises three strategic objectives of strengthening the capacity of the rural poor and their organisations, improving equitable access to productive natural resources and technology and increasing access to financial services and markets in order to achieve poverty reduction [59; 79]. Institution building is now recognised as vital for poverty reduction across the world [72]. To enhance international development, the United Nations Organisation (UNO) announced the MDGs which aimed to eradicate poverty by 2015 . Governments, donors and NGOs around the world responded enthusiastically with plans and promised to work together towards the realisation of these goals. In the recognition of micro finance, the UNO celebrated the year 2005 as a year of micro credit, as a result this financing instrument is perceived worldwide as a very effective mean against hunger and poverty, mainly in developing countries [84].

The microcredit programme through Self Help Group (hence forth $\mathrm{SHG}$ ) is a unique innovation of credit delivery technique to enhance income generating activities. Self Help Group is a method of organising the poor people and the marginalised to come together to solve their individual problem. Self Help Group-Bank Linkage Programme (SBLP) is emerging as a cost effective mechanism for providing financial services to the "unreached poor" which has been successful not only in meeting financial needs of the rural poor women but also strengthen collective self help capacities of the poor, leading to their empowerment both economically and socially. Micro finance emerged in the 1970 s as social innovators began to offer financial services to the working poor those who were previously considered 'unbankable' because of their lack of collateral. Micro Finance Institutions (MFIs) are now innovating to empowering the world's poor to improve their own lives. In the globe, such programmes are becoming increasingly popular. It is believed that they will lead to poverty reduction, unemployment, empowerment of women and inclusive growth. The programme extends small loans to poor people for self-employment activities, thus, allowing the clients to achieve a better quality of life $[57,92,115]$. 
Micro Credit Summit [86] also reported micro finance and its relevant programmes is the most sensational antipoverty tool for the poorest, especially for women. It has been quite well recognised that micro finance smoothens consumption, reduces the vulnerability of the poor and leads to increase in their income. By giving the world's poor a hand up, micro finance can help to break the vicious cycle of poverty in as little as a single generation [77].

Micro finance programme like SBLP, SGSY or MFI linkage have a positive impact on both economic and social empowerment on the women members along with reduction in poverty. The relevance of SHGs as powerful instruments of social, political and economic empowerment of women has also been unanimously accepted by researchers $[10,60,130]$. A lot of researchers have also showed their negative experiences on micro finance [116]. Thus, from literature reviews of empirical research on the impact of micro finance on the poor found controversial (and inconclusive) findings.

- A lot of literature on impact of micro finance and SHGs on members are reviewed and these can be broadly classified as under [78].

- A lot of studies experienced beneficial socioeconomic impact of micro finance and SHGs on members, such as income stability and growth, reduced income inequality, reduced vulnerability, employment, nutrition and health improvements, school attendance, strengthened social networks, and women's empowerment $[4,15,16,19,50,51$, $70,127,138,140]$.

- A lot of studies expressed mixed impact of micro finance and SHGs on members. For example, benefits for the poor but not for the poorest $[33,52$, 91, 93, 134, 142]; or helping the poor to better manage the money they have [120] but not directly or sufficiently increasing income, empowering women, etc. [81, 56, 113]; or supporting large labour-intensive industries for job creation $[67,75]$.

- A lot of studies reported negative impact of micro finance and SHGs on members, such as the exploitation of women, unchanged poverty levels, increased income inequality, increased workloads, high interest rates and loan repayment, creating dependencies, and creating barriers to sustainable local economic and social development [2, 18, 24, 32, 47, 64, 119].

Further, despite the apparent success and popularity of micro finance, no clear evidence yet exists that micro finance programme have positive impacts [12, 13]. Four major reviews as cited in Stewart et al., 2010 [133] examining impacts of micro finance $[42,48,104,105,128]$ concluded that while anecdotes and other inspiring stories [137] purported to show that micro finance can make a real difference in the lives of those served, rigorous quantitative evidence on the nature, magnitude and balance of micro finance impact is still scarce and inconclusive [12, 13]. Overall, it is widely acknowledged that no well-known study robustly shows any strong impacts of micro finance [12]. A series of studies have been raised serious doubts about the effectiveness of micro finance programmes among the most vulnerable sections of the society $[8,30$, 54, 61, 62, 88, 131]. These studies have pointed that inflexibly and non-negotiable repayment systems are found to be too hard for the poorest sections which many at times compel them to sell their assets to meet the deadlines of their contribution and repayment [131]. The stringency of repayment rules has a series of negative implications for the poor members. A number of studies have pointed out that micro finance members are quite often completed to depend on informal credit sources and money lenders for the timely repayment of loans $[6,114]$. The impact of peer pressure and possibility of negative social sanction on the defaulted members and the resultant straining of relationships have been amply demonstrated by the scholars [89, 90, 139]. In the latter half of 2010 the micro finance industry made news for negative reasons. By October of that year regulation of the micro finance industry through the Micro Finance Institutions Ordinance, 2010 in Andhra Pradesh, India elicited much debate. The concerns of this ordinance were high interest rates of between $27 \%$ and $30 \%$ charged by MFIs, the practice of multiple lending, splitting self help groups to form joint liability groups, and coercive collection tactics that were blamed for the suicides by borrowers [69, 117].

Thus, Micro-finance has created considerable thrust and expectations among the academics, policy makers of the Government, NGO leaders, donors, investors and other development practitioners in all over the world. In essence, micro-finance has produced positive impacts on three vital areas of national development - alleviation of poverty, social development and women's empowerment. A lot of research persuaded to access the impacts of SHGs on members on different sphere like economic, social, and other aspects. One modest effort has been initiated by SaDhan, 2003 [122] in preparing and publishing a discussion paper on 'Quality Parameters of SHGs', wherein a lot of issues sets out in the quality assessment of SHGs. Moreover, the paper also set out some unresolved key issues for further discussion and research. Thus, the present study is limited to one of the unresolved issues of quality assessment of SHGs as raised by Sa-Dhan.

\section{Impact of Self Help Group on Members in India: A Review}

It is fairly clear from the literature as reported above that the state of impact assessment in micro finance, more specifically community organisations such as SHGs is still undeveloped in general and very nascent stage in India. A lot of micro level studies were conducted so far in India on impact of SHGs on members. However, all these studies are confined to one or more of the followings facts.

- $\quad$ Saving and financial decision making: It is reported 
in many studies that primary benefits of participation in SHG is the opportunity to save regularly, access formal savings institutions and participate in the management of these savings [22, 43, 83, 97, 99, 112, 125, 141].

- Access to credit: A corollary of participation in SHGs is an improvement in a woman's access to credit. The financial mobility due to participation in the SHG has led to an improvement in the quality of life, according to some of the successful groups. Overall, many families were able to address their basic needs better than before which is also reported in many studies $[22,99,125,141]$.

- Employment: The implementation of SHG has generated self-employment opportunities by establishing own income generating units. The programme helped many participants in improving their economic conditions [20, 22, 124].

- Decision-making within the household: It is also reported in many studies that the impact of the SHG programme increased involvement in household decision-making. Researcher observed that there is a change in the attitude of male members of the families, especially in children education, schoolings decisions, sanitation etc. $[65,71,80,96$, 99, 109, 111, 125, 130].

- Participation in local government: Involvement in SHG has resulted further involvement in the democratic set up either in the SHG leadership or in participation in local bodies. These impacts of SHGs are also refereed in many studies $[1,38,106]$.

- Communication level of members: Micro finance movement is having a good impact on members, in their ability to express their feelings and has made people more confident to express themselves [31, $80,99,125,109]$.

- Self confidence among members: The group formation brought out the hidden talent and leadership qualities among the members. Therefore, it can be concluded that after joining the SHG the members have improved their status in family, skill and feel confident in establishing economic units. They now feel confident in consultation with government, non-government and bank officials these things. Members generally, got lesser opportunity to interact with bankers, Government officials, NGOs and others in the Pre-SHG period. Involvement confidence to interact with the officials. Such interaction helped them to articulate their problems and improved their self-confidence [5, 25, 31, 80, 107, 118].

- Change in family violence: Involvement with SHG has reduced domestic violence which was also reported in research studies [21].

- Status of access to amenities: Since SHG programme has economic as well social implications. It can be seen that there has been an increase in standard of living in terms of their status of access to amenities factors. It is reported that after joining the SHG the members have improved in getting access to amenities like medical, sanitation, education, market, water supply, transport [31, 96, 132].

- Community participation: SHG members undertook a lot of community activities. They participated in several social \& community development initiatives and other social welfare programmes. Involvement in such programmes resulted interaction with experts has resulted in building congenial relationships and has ensured fewer conflicts. It has also had the multiplier effect of spreading the SHG movement. Awareness of health related issues, personal hygiene, communicable diseases; effects of malnutrition, environmental issues, and sanitation have also increased as a result of training programmes and their participation in the related projects. They also organises a lot of community development events which are also observed by many researcher [28, 31, 96, 111].

- Increased nutritional status: Researcher also observed positive impacts on nutritional intake of the family members of SHGs [36, 41, 87].

- Disseminating social awareness: Members of SHGs spread social awareness among people of their locality and villages. They make people aware of their social rights \& responsibilities. Involvement in SHGs by the women have positive influence on achieving lower child mortality, improved maternal health, better nutrition, housing \& health [96].

- SHGs and environmental management: Research and policy has tended to focus on the relationship between poverty and environmental degradation in terms of pointing out that the poor are both victims and agents of environmental degradation. Involvement of SHG members in development programmes through SHGs can effectively increase awareness of society to ward environmental sustainability.

- Improving the efficiency of credit system: The SHG helps the vulnerable sections of the society to meet their credit requirements that cannot be possible through formal banking system. Further, by providing large scale micro credit, it reduces the costs of credit delivery and improves the efficiency of credit system.

- Providing channels to financial inclusion: Financial inclusion aims at providing easy credit at affordable costs to the vulnerable sections of the society. SHGs are an important tool in financial inclusion. Moreover, through SHGs funds are provided mostly to socially and economically backward people like BPL, SC, ST and rural women etc.

- Helps in resource mobilisation: SHGs plays a crucial role in mobilising the savings of the poor. 
- Promoting savings \& banking habits: A large number of poor, rural populations do not have access to banks. SHGs motivate these people to save by explaining to members the benefits derived from such savings. These savings are pooled together and the funds so created are deposited in the banks.

- Improving living conditions: One of the main aim of SHGs is reduction of poverty in rural in rural areas. The provision of micro credit leads to self employment in the rural areas and help reduction in poverty. This improves the living conditions of the people. Moreover, membership in SHGs enabling poor households to achieve better school attendance and lower dropout rates of their kids.

- Developing individual skills of group members: The rural people are not very educated or skilled. While working as members of SHGs, they develop various skills and acquire knowledge on various subjects like record keeping, credibility, effective problem solving, team work, leadership etc.

- $\quad$ Reducing influences of unorganised sectors: SHGs provide bank supported credit to its members. This reduces the influences of the unorganized sector of money market who charge exorbitant rate of interest, on the credit provided to the people.

\section{Operationalising the Concepts}

Impact assessment is a management mechanism aimed at measuring the effects of projects on the intended beneficiaries. The rationale is to ascertain whether the resources invested produce the expected level of output and benefits as well as contribute to the mission of the organisation that makes the investments. An almost infinite array of variables can be identified to assess impacts on different units. To be of use these must be able to be defined with precision and must be measurable. Conventionally, economic indicators have dominated micro-finance impact assessments with assessors particularly keen to measure changes in income despite the enormous problems. Other popular variables have been levels and patterns of expenditure, consumption and assets.

As the 'social' sphere of impact is the focal point of this research, it is pertinent to have a very clear understanding of how the term is perceived in development research and academic circles and how it will be connoted in this study. Neubert, 2000 [101] describes it as 'concerning the order of human society', by referring to it as a concept that pertains to the relationship between individuals, between individuals and groups, and between groups within a society. Variables of social impact refers to measurable changes to the human population, communities and social relationships resulting from development initiatives instigated by third sector organisations- NGOs or MFIs. Broadly speaking, these variables pertain predominantly to indicators proposed by various institutions in an attempt to set forth a standardised and measurable set of indices that determine human well-being in a society. The social indicators that became popular in the early 1980s (e.g. educational status, access to health services, nutritional levels, anthropometric measures and contraceptive use etc.) have recently been extended into the socio-political arena in an attempt to assess whether micro finance can promote empowerment $[47,49,82,126]$. Social impact by means of micro financing activities and its evaluation can be best understood by means of a standard model. But there are no well acceptable model so far developed to access social impact [45]. The Annual Human Development Report [55] published by the United Nations Development Programme (UNDP) makes use of a number of such indicators that attempt to portray, amongst other aspects, the social wellbeing of people around the world [55] viz, the Human Development Index (HDI), Gender-related Development Index (GDI), the Gender Empowerment Measure (GEM), the Quality-of-Life Index (QLI), the Economist Intelligence Unit (EIU) etc. In 2003, the foundation Argidus, the CERISE (2000) and several European researchers had developed the initiative Social Performance Indicators [63]. It is conceived like an instrument of analysis, which can stimulate the internal reflection on the MFI or between its managers and their stakeholders as for the social objectives and the realisations and perspectives of the institution. The Consultative Group to Assist the Poor (CGAP) rates the social performance of MFIs, from the main five dimensions of the Millennium Development Goals: i) Proportion of clients below the line of the poverty; ii) Improvement of the savings of the clients; iii) Improvement of the presence in the school of the children and reduction of the illiteracy; iv) Improvement on the access to the services of health; and v) Progress in terms of women empowerment. Further, the Inter-organisational Committee on Guidelines and Principles for Social Assessment, 1994 [46] presents an allencompassing description of Social Impact Assessment [58] and suggests that cultural impacts also constitute an important element while assessing social impacts.

Further, here in this research study the words 'core components' refers as the heart or inner part of social impact facilitated by the SHG members. It is considered as the central part of issues of social impact that often enjoys by SHGs. On the other hand, 'Peripheral Component' means on the outer part of something. Its meaning, so far as technology/ issues are concerned, is the same. Since the study access the perceptions of the direct stakeholders of SHGs regarding the issue whether impact on members of SHGs and its involvement in large social issues is Peripheral components of quality indicators or not, hence all social impact issues that may impact the SHG members are incorporated in the research study.

Sinapi Aba Trust (SAT) and Soweto Microenterprise Development/SOMED [3] project studies [4] formulated four broad impact indicators or domains such as economic domains, access to life-enhancing facilities, and social and spiritual domains while assessing the impact of the 
programme. Reviews of literature were also made to find out suitable indicators on the impact of SHG on both social and economic sphere that were used by different researcher and also to be considered for the present study $[11,14,16$, $17,23,27,35,37,39,53,66,68,73,80,94,94,100,109$, $110,107,123]$. Several researchers have reported that SHGS contribute in other areas of economic development and growth such as poverty eradication, social transformation and empowerment [9, 14, 29, 102, 135].

From the survey of literature cited above, sixty five statements on impacts- indicators relating to social issues are identified and included to study the perceptions of different stakeholders on SHG whether the aspects like impact on members of SHG and its involvement in larger social issues should be peripheral or core components of quality indicators of SHG (Figure 1).

\section{Objective of the Study}

The present study is pursued keeping in view the following main objectives

a) To examine the opinion of the direct stakeholders (viz. Promoters, Donors, Financial Institutions and the Group members) whether the aspects like impact on members of SHG and its involvement in larger social issues should be peripheral or core components of quality indicators of SHG.

b) To forward conclusion based on the findings of the study.

\section{Research Hypotheses}

Given the survey of literature and objectives, the study is pursued to test the following statistical hypothesis:

Ho: There is no significant association in the opinion of the direct stakeholders (viz. Promoters, Donors, Financial Institutions and the Group members) of SHGs regarding the issue whether impact on members of SHGs and its involvement in large social issues be peripheral or core components of quality indicators.

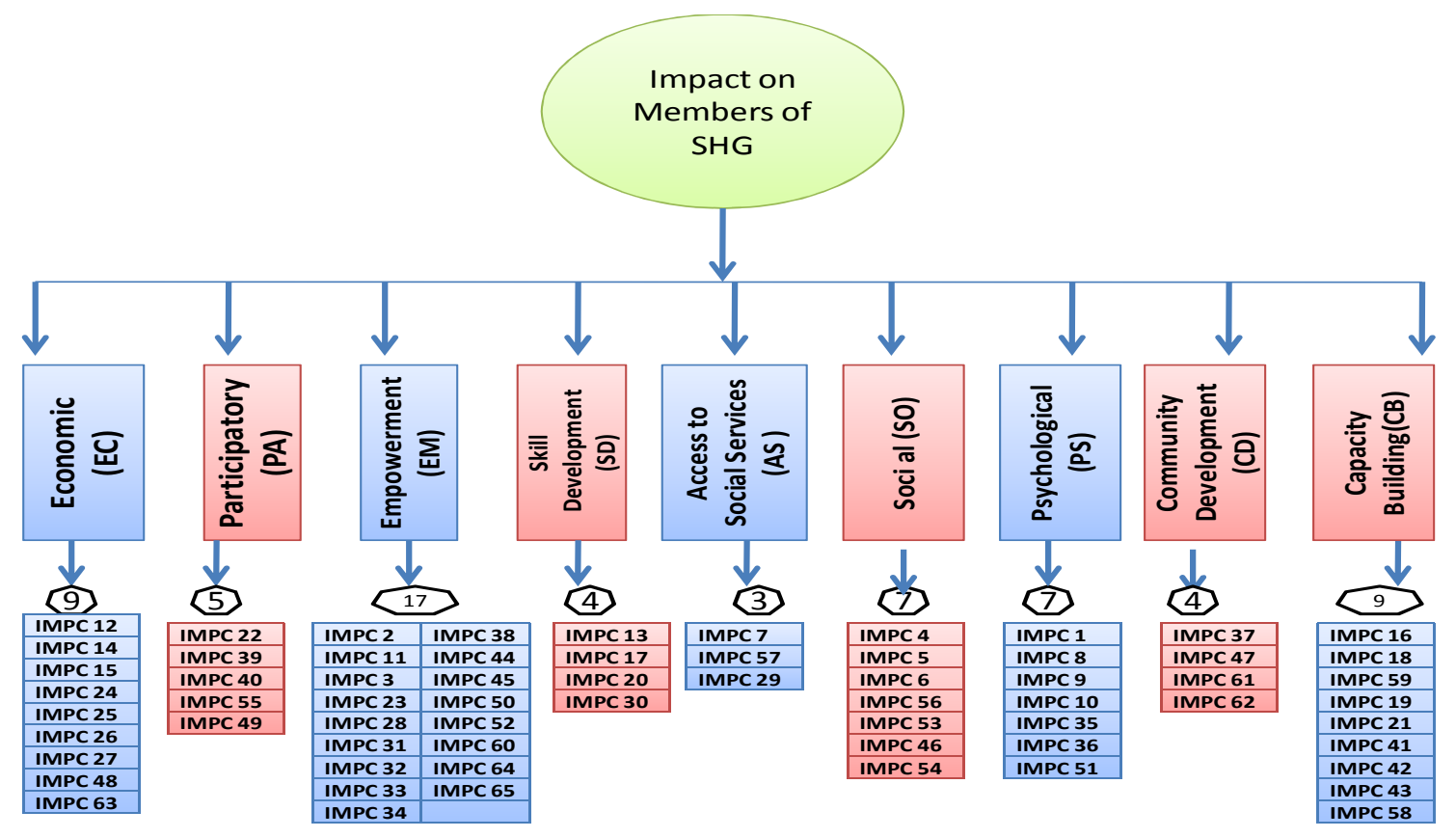

Figure 1. Subscales for assessing Impact of SHG on Members- Core Issue vs. Peripheral Issues Source: Designed based on Survey of Literature

\section{Methodology and Sample Design}

The research design and methodology devised in this paper is being presented which has been designed keeping in mind the focused objectives and with the aim of acquiring accurate and authentic data. The methodology of research is descriptive in nature and empirical method is also applied to assess perceptions of direct stakeholders on the issue of SHGs as financial intermediaries. As the study adopted a descriptive study design; this design was crucial in capturing the socio-economic characteristic of the study groups such as demographics data, economic status, social benefits, and entrepreneurial activities. As explained by
Mugenda [93] it helped in collecting data concerning behavior, attitude, values and characteristic. Multi-stage random sampling method is used for the present study to collect primary data. Nagaon district of Assam was purposively chosen out of twenty seven districts of Assam for the present study. At the next level, five Development Blocks are selected randomly. In the later stage, three revenue villages from each of the selected Development Blocks are purposively selected. From each revenue village, three SHG members, who are associated actively, are selected randomly. In this way 45 SHGs were selected out of which one member of a group failed to response. Further, 12 Financial Institutions i.e. nationalised commercial bank and RRBs (operating in the study area); 10 Donors and 34 
Promoters including banks, NGOs, NGO-MFI, Farmers Club and Government Departments are also selected randomly who are directly associated with the sampled SHGs. In selecting the sample size earlier studies of researchers are duly considered [103]. Primary data was collected from the 100 sample respondents using pre-tested questionnaire. Key information about SHGs and stakeholders are collected from the office of the DRDA, Nagaon, Assam and SHGs which are existed above two years and involved in income generating actives are cover within the purview of study. The study was conducted during 2012. Secondary data was collected from report and journals. The important variables were formulated and the relevant data collected from the field were coded and analysed using SPSS (Statistical Package for Social Sciences) software. Perceptions of direct stakeholders whether SHG is a financial model were expressed based on 5 Point Scale where SA= Strongly Agree (2), A = Agree (1), NAND $=$ Neither agree nor disagree (0), DA = Disagree ($1)$, and SDA $=$ Strongly disagree $(-2)$. Further, the data collected was analysed using the measure of descriptive statistics like mean, variance, standard deviation, maximum, minimum etc. Further, Cronbach alpha, Normality Test i.e. Kolmogorov- Smirnov Test, and ANOVA were applied in analysing and interpreting the data.

\subsection{Profile of the Study Area}

The Central Assam District of Nagaon (spelled by the British as Nowgong) is one of the largest districts of Assam. It sprawls across almost four thousand square kilometers of fertile alluvial plains and thickly forested hills. Nagaon extends from 250-45' to 260-45' North Latitude and 92033'-6" East Longitude. The district is bounded by Sonitpur district and the river Brahmaputra in the north, West Karbi Anglong and North Cachar Hills in the south and East Karbi Anglong and Golaghat district in the east. The mighty river Brahmaputra flows along the northern periphery of the district. Other major tributaries meandering through the district such as Kolong, Kopili drain into the Brahmaputra. Lying at a distance of 123 kilometers by road from Guwahati, Nagaon town constitutes a vital corridor linking the Upper Assam districts of Golaghat, Jorhat, Sivasagar, Dibrugarh, Tinsukia and the North Assam districts of Sonitpur and North Lakhimpur. Nagaon has covered total area of 3,993 sq. km. The demographic profiles of the study district are briefed in Table 1.

The SHG linkage approach operating in the districts of Nagaon is to some extent similar with the state structure. While we undertook pilot survey at preliminary stage in order to examine whether all models exist in practice, we found NGO as MFIs and NGO as financial intermediary did not exist separately. Therefore, Model II A and Model II $\mathrm{B}$ have been clubbed together into a single category termed as Model II (NGO as Financial Intermediary). Further, three MFI and fifty four Farmer Clubs are also promoted SHGs in the district. Besides, there are five Cooperative
SHGs in the district of Nagaon (Micro Finance Status Report, NABARD 2010-11, and SLBC Report, March 2010).

Table 1. Demographic Profile of Nagaon District of Assam, India

\begin{tabular}{|c|c|c|}
\hline $\begin{array}{l}\text { Demographic } \\
\text { Indicators }\end{array}$ & Values & \\
\hline Total Population & $\begin{array}{l}2,826,006 \quad[1,440,307 \quad \text { (Males), } \\
\text { (Female) }]\end{array}$ & $1,385,699$ \\
\hline Total ST Population & 89394 & \\
\hline Total SC Population & 215209 & \\
\hline Male literacy & $78.19 \%$ & \\
\hline Female literacy & $69.21 \%$ & \\
\hline Population Density & 711 per sq. $\mathrm{km}$ & \\
\hline Total House Holds & 378778 & \\
\hline BPL House Holds & 177697 & \\
\hline BPL P/C & 46.91 & \\
\hline No. of SHG Formed & $24156^{*}$ & \\
\hline
\end{tabular}

*Upto March 2011

Source: Census Report 2011 and Microfinance Status Report, NABARD 2010-11

Further, the overall progress of SHGs under SHG-Bank linkage and MFI-Bank linkage in the study district are shown in the below Table 2 .

To get rid from poverty and to increase in income are the main motivating factors to join SHGs \& the process that lead to the formation of a SHG is at the desire of promoter to achieve the target-oriented approach of SHG promotion. In Nagaon district, SHGs are formed and organised under directly or the other umbrella programmes of the Government, NGOs, banks and sometimes, even by the people themselves.

\subsection{Profile of the Respondents}

Profile of sample respondent's (who are direct stakeholders of SHGs viz. Promoters, Donors, Financial Institutions and the Group members) are depicted in the Table 3 which is self explanatory. 'Stakeholders' means the persons or institutions with whom any stake or interest is vested or created to facilitate the promotion of SHG movement, which shall include the regulators, promoters, donor, financier, educators and facilitators of the SHG movement. Major stakeholders in SHGs are, therefore includes all Self Help Promoting Institutions (SHPIs) i.e. Promoter, Donor, Financier and the SHGs itself. SHPIs, whether Farmers club, NGOs, banks or State governments, have been playing a vital role in promoting, nurturing and sustaining the SHG movement under SBLP in Assam. It is observed that the major promoter of SHGs in the study districts are DRDA (for SGSY scheme), followed by NGOs and Banks. A few NGO-MFI are also promoting SHGs in the study district. In this study respondent as promoter includes some officials of NGOs such as ASOMI, Prochesta-MFI, RGVN-MFI, Commercial banks, SIRD, DDM-NABARD, ASFABC, Agriculture Departments, Farmers Club etc. who are engaged in SHG promotion. 'Donors and investors' encompasses a range of funding 
agencies, including bilateral donors, foundations, multilateral development banks, and socially oriented private investors. While NABARD and RMK etc. remains a major donor to NGOs and SHG institutions in India and have been receiving a fraction of required funds for their development. In the study district, NABARD, State Government under SGSY and NGO-MFIs are the major donors of SHGs. In this study respondents belonging to Donor includes some officials of NGO-MFI such as ASOMI, Prochesta-MFI, RGVN-MFI, Dristi Foundation, RuTAG-NE, Srimanta Sankardeb Sangstha; Officials of
District Veterinary \& Animal Husbandry, NABARD, NERCRMP, SIRD, Agriculture Departments etc. SHPIs include banks, NGOs, NGO-MFIs and state governments. Here in the state of Assam and even in the study district SHPIs acts both promoter and financier. However for the sake of convenience of study, we have collected perceived opinions of different stakeholders on different scale of capacity, i.e. bank is considered financier, promoter and donor. In this study respondents belonging form Financial Institutions includes Officials of nationalised commercial banks including SBI, RRBs i.e. AGVB etc.

Table 2. Progress of SHGs in Nagaon, Assam (As on $31^{\text {st }}$ March 2011)

\begin{tabular}{llll}
\hline Promoter & No. of SHG Formed & No. of SHG taken up Economic activity & No. of Women SHGs Formed \\
\hline & Total* & Total & Total \\
SGSY & 20590 & 5592 & 12630 \\
Asomi-MFI & 24 & 15 & 22 \\
Prochesta- MFI & 64 & 35 & 37 \\
RGVN- MFI & 87 & 56 & 64 \\
NGO-MFI & & & 44 \\
SK Human Welfare Assoc. & 50 & 27 & 38 \\
Gharoa** & 50 & 28 & 48 \\
Jana Chetana Samity Asom & 62 & 24 & 40 \\
Zeal Thrill Friend-ship & 50 & 10 & 26 \\
Group** & 31 & 11 & 132 \\
Gramya US & 165 & 56 & 168 \\
Bank*** & 258 & 123 & 87 \\
Farmer Club / SHG & 121 & 13336 \\
as Cooperative society & 2725 & 6098 & \\
Others including Govt. Depts. & 24156 & & \\
Total & & & 46 \\
\hline
\end{tabular}

*Total since $1^{\text {st }}$ April, 1999;**Promoted with Banks, ***Reported from SLBC Report, March 2010.

Source: Microfinance Status Report, NABARD 2010-11, and SLBC Report, March 2010

Table 3. Distribution of the Sample Respondents

\begin{tabular}{lll}
\hline Variables & & Number (Percentage) \\
\hline A. Socio-economic Profile of Group members & & \\
1. Gender of SHG Member & Male & $24(54.5 \%)$ \\
& female & $20(45.5 \%)$ \\
2. Age & Below 30 yr & $11(25 \%)$ \\
& $30-40$ yr & $12(27.3 \%)$ \\
& $40 \&$ above & $21(47.7 \%)$ \\
3. Caste of Group Members & General & $22(50 \%)$ \\
& Schedule Caste & $13(29.5 \%)$ \\
& Schedule Tribes & $7(15.9 \%)$ \\
4. Social Status of Group Members & Others & $2(4.5 \%)$ \\
& Most Backward Community & $3(6.8 \%)$ \\
& Backward Community & $27(61.4 \%)$ \\
5. Economic Status of Group Members & Forward Community & $14(31.8 \%)$ \\
& Below Poverty Level & $15(34.1 \%)$ \\
& Green Card Holder & $7(15.9 \%)$ \\
& Job Card Holder & $4(9.1 \%)$ \\
6. Duration of Membership in SHG & Others & $18(40.9 \%)$ \\
& $1-4$ yr & $17(38.4 \%)$ \\
7. Literacy Level of Group Members & $4-5$ yr & $15(34.1 \%)$ \\
& $5-6$ yr & $4(9.1 \%)$ \\
& Above 6 yr & $8(18.2 \%)$ \\
& Primary & $9(20.5 \%)$ \\
& Below 10th Std. & $4(9.1 \%)$
\end{tabular}




\begin{tabular}{|c|c|c|}
\hline Variables & & Number (Percentage) \\
\hline \multirow{4}{*}{ 8. Annual Income of Group Members } & 10th Std. & $11(25 \%)$ \\
\hline & Above 10th Std. & $20(45.5 \%)$ \\
\hline & Upto Rs. 50 Thousand & $25(56.8 \%)$ \\
\hline & Rs. 50- Rs. 1 lakhs & $19(43.2 \%)$ \\
\hline \multicolumn{3}{|l|}{ B. Profile of Other Stakeholder } \\
\hline \multirow[t]{3}{*}{ 9. Nationality of Other Stakeholders } & Indian & $34(100 \%)$ \\
\hline & Govt. Depts. & $7(20.6 \%)$ \\
\hline & Other Govt. Agencies & $19(55.9 \%)$ \\
\hline \multirow{4}{*}{ 10. Nature of Promoting Organisation } & NGO- Universal & $1(2.9 \%)$ \\
\hline & NGO- Nation hood & $3(8.8 \%)$ \\
\hline & NGO-Region hood & $2(5.9 \%)$ \\
\hline & NGO- Statehood & $2(5.9 \%)$ \\
\hline \multirow{3}{*}{ 11. Place of Location of Stakeholders } & Assam & $\begin{array}{l}\text { Promoter }=18(52.9 \%) ; \text { Donor }=6(60 \%) ; \mathrm{FI}=4(33.3 \%) \text {; } \\
\text { Total }=28(50 \%)\end{array}$ \\
\hline & $\begin{array}{l}\text { Outside Assam but } \\
\text { within NER }\end{array}$ & Promoter $=2(5.9 \%) ;$ Donor $=2(20 \%) ;$ Total $=4(7.14 \%)$ \\
\hline & Outside NER & $\begin{array}{l}\text { Promoter }=14(41.2 \%) ; \text { Donor }=2(20 \%) ; F I=8(66.7 \%) ; \\
\text { Total }=24(42.86 \%)\end{array}$ \\
\hline \multirow[t]{2}{*}{ 12. Nature of Programme/ Project of Stakeholders } & SGSY & $\begin{array}{l}\text { Promoter }=19(55.9 \%) ; \text { Donor }=3(30 \%) ; \mathrm{FI}=12(100 \%) ; \\
\text { Total }=34(60.71 \%)\end{array}$ \\
\hline & Others & Promoter $=15(44.1 \%) ;$ Donor $=7(70 \%) ;$ Total=22(39.29\%) \\
\hline \multirow{2}{*}{ 13. Nature of Promotion by Stakeholders } & Financial & $\begin{array}{l}\text { Promoter }=18(52.9 \%) ; \text { Donor }=1(10 \%) ; \text { FI }=11(91.7 \%) \text {; } \\
\text { Total }=30(53.57 \%)\end{array}$ \\
\hline & Both & $\begin{array}{l}\text { Promoter }=16(47.1 \%) \text {; Donor }=9(90 \%) ; \mathrm{FI}=1(8.3 \%) \text {; Total } \\
=26(46.43 \%)\end{array}$ \\
\hline \multirow{4}{*}{$\begin{array}{l}\text { 14. Recovery Percentage of SHG Promoted by } \\
\text { Different Stakeholders }\end{array}$} & Below 25\% & Nil \\
\hline & $25-50 \%$ & Donor $=6(60 \%) ;$ Total $=6(27.27 \%)$ \\
\hline & $50-75 \%$ & FIs $=10(83.3 \%) ;$ Donor $=4(40 \%) ;$ Total $=14(63.64 \%)$ \\
\hline & Above $75 \%$ & FIs $=2(16.7 \%) ;$ Total $=2(9.09 \%)$ \\
\hline \multirow[t]{2}{*}{ 15. Impact Assessment by Stakeholders } & No & $\begin{array}{l}\text { Promoter }=27(79.4 \%) ; \text { Donor }=5(50 \%) ; \text { FI }=12(100 \%) ; \\
\text { Total }=39(69.64 \%)\end{array}$ \\
\hline & Yes & Promoter $=7(20.6 \%) ;$ Donor $=5(50 \%) ;$ Total $=12(21.43 \%)$ \\
\hline \multirow{2}{*}{ 16. Quality Assessment Conducted by Stakeholders } & No & $\begin{array}{l}\text { Promoter }=23(67.6 \%) ; \text { Donor }=6(60 \%) ; \mathrm{FI}=9(75 \%) ; \text { Total } \\
=38(67.86 \%)\end{array}$ \\
\hline & Yes & $\begin{array}{l}\text { Promoter }=11(32.4 \%) ; \text { Donor }=4(40 \%) ; \mathrm{FI}=3(25 \%) \text {; Total } \\
=18(32.14 \%)\end{array}$ \\
\hline \multirow{2}{*}{$\begin{array}{l}\text { 17. Performance Assessment Conducted by } \\
\text { Stakeholders }\end{array}$} & No & $\begin{array}{l}\text { Promoter }=15(44.1 \%) ; \text { Donor }=4(40 \%) ; F I=5(41.7 \%) ; \\
\text { Total }=24(42.85 \%)\end{array}$ \\
\hline & Yes & $\begin{array}{l}\text { Promoter }=19(55.9 \%) ; \text { Donor }=6(60 \%) ; \mathrm{FI}=7(58.3 \%) ; \\
\text { Total }=32(57.14 \%)\end{array}$ \\
\hline \multirow{3}{*}{ 18. Nature of Donor Organisation } & Govt. Dept & $5(50 \%)$ \\
\hline & Trust & $3(30 \%)$ \\
\hline & NGO & $2(20 \%)$ \\
\hline \multirow{2}{*}{ 19. Nature of Financial Institution } & Public Sector FI & $9(75 \%)$ \\
\hline & RRBs & $3(25 \%)$ \\
\hline
\end{tabular}

Source: Compiled from questionnaire

\section{Analysis and Discussion}

\subsection{Reliability Test}

To understand the reliability of the field data, Cronbach's alpha test was conducted which reveals that Cronbach's Alpha is 0.832 which is considered good and further denotes that there are the presences of internal consistency $[34,44,103]$.

\subsection{Validity}

The instrument used in this study was developed by the researchers after an extensive review of literature in the subject and related theory and following survey design procedures found in the literature [7, 40, 74, 76]. We drafted a pool of 100 items, which were submitted to 4 content judges for review and to determine the face and content validity of the items. These judges had expertise in research design, survey design, micro finance management and group development. This panel of content judges included local university faculty members and micro finance practitioners of repute. We requested this panel to check the instrument items for clarity, length, time to complete, difficulty in understanding and answering questions, flow of questions, appropriateness of questions based on the research topic, any recommendations for 
revising the survey questions (e.g., add, substituted or delete), and overall utility of the instrument. Based on their feedback, some items were dropped and others reworded where necessary. At this stage, the 100 items relating to impact on members of SHG and its involvement in larger social issues were reduced to 65 .

Table 4. Descriptive on Perception of Stakeholders of SHG on Impact-Peripheral or Core Component of Quality Indicators of SHG

\begin{tabular}{|c|c|c|c|c|c|c|c|c|}
\hline \multirow{2}{*}{ Overall Score on (IMPC) } & \multirow{2}{*}{$\mathbf{N}$} & \multirow{2}{*}{ Mean } & \multirow{2}{*}{ Std. Deviation } & \multirow{2}{*}{ Std. Error } & \multicolumn{2}{|c|}{$\mathbf{9 5 \%}$ Confidence Interval for Mean } & \multirow{2}{*}{ Minimum } & \multirow{2}{*}{ Maximum } \\
\hline & & & & & Lower Bound & Upper Bound & & \\
\hline Promoter & 34 & 21.7941 & 12.20477 & 2.09310 & 17.5357 & 26.0526 & -2.00 & 46.00 \\
\hline Donor & 10 & 33.2000 & 16.24671 & 5.13766 & 21.5778 & 44.8222 & 8.00 & 67.00 \\
\hline Financial Institutions & 12 & 17.5000 & 12.50818 & 3.61080 & 9.5527 & 25.4473 & -2.00 & 39.00 \\
\hline Group Members & 44 & 23.0682 & 14.52087 & 2.18910 & 18.6534 & 27.4829 & -14.00 & 60.00 \\
\hline Total & 100 & 22.9800 & 14.04609 & 1.40461 & 20.1930 & 25.7670 & -14.00 & 67.00 \\
\hline
\end{tabular}

Source: Compiled from the Questionnaire

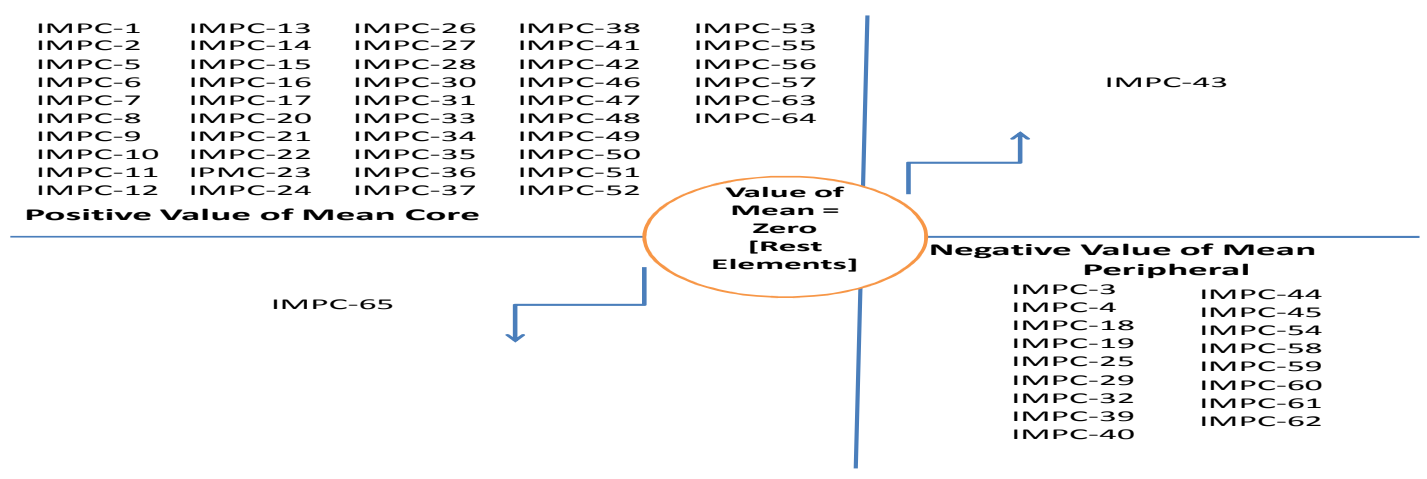

Figure 2. Item wise Descriptive on Statements on Impact on member of SHG \& Involvement in Social Issues

Table 5. One-Sample Kolmogorov-Smirnov Test on Perception of Stakeholders of SHG on IMPC

\begin{tabular}{lll}
\hline Overall Score on IMPC & & Values \\
\hline $\mathrm{N}$ & & 100 \\
\multirow{2}{*}{ Normal Parameters $^{\mathrm{a}, \mathrm{b}}$} & Mean & 22.980 \\
& Std. Deviation & 14.046 \\
& Absolute & .075 \\
Most Extreme Differences & Positive & .074 \\
& Negative & -.075 \\
Kolmogorov-Smirnov Z & & .751 \\
Asymp. Sig. (2-tailed) & & .625 \\
\hline
\end{tabular}

a. Test distribution is Normal.

b. Calculated from data.

Source: Compiled from the Questionnaire

\subsection{Descriptive Statistics}

Further, the descriptive scale statistics on the perception of different stakeholders on whether the aspects like impact on members of SHG and its involvement in larger social issues should be peripheral or core components of quality indicators of SHG denotes the mean value 22.98, variance 197.293 and Standard Deviation is 14.046 (Table 4).

\subsection{Normality Test}

Here two tests for normality are run viz. KolmogorovSmirnov test and Shapiro-Wilk. In our case, since we have only 65 elements, the Shapiro- Wilk test is used and the pvalue revealed as 0.312 . We can accept the null hypothesis and conclude that the data are comes from a normal distribution. Similarly, individual item wise tests of
Normality under two different Test viz. KolmogorovSmirnov test and Shapiro-Wilk is also conducted and found that $\mathrm{p}$-value is 0.000 . Hence, we reject the null hypothesis and conclude that the data are not comes from a normal distribution. Therefore, to get a clear picture about the issue on normality we resorted to K-S Z Test. It is observed since the p-value is 0.625 for Overall Score of variables on Impact- Peripheral or Core, there is no reason to doubt the distribution is normal, so we can safely proceed with the 'ANOVA' test. (Table 5).

\subsection{ANOVA Analysis}

From Table 6 the ANOVA output, (ANOVA) is the key table because it shows whether the overall $F$ ratio for the ANOVA is significant. In case of Overall Score on ImpactPeripheral or Core, $F$ ratio (2.572) is significant ( $p=0.059$ ) at the .05 alpha level. It is observed that $F(3,96)=2.572$, $p \geq .05$. We conclude that at least one of the group means is not significantly different from the others (or that at least two of the group means are not significantly different from each other). In brief, there was no significant effect of Stakeholders on overall score on Impact on members of SHG as Peripheral or Core issue remembered at the $\mathrm{p} \geq .05$ level for the three conditions $[\mathrm{F}(3,96)=2.572, \mathrm{p}=0.059]$.

Since in the overall score of variables on Impact on members of SHG as Peripheral or Core issue, it is statistically proved that the means form all four groups are not equal (Table 4) hence, we resorted to find out item wise analysis on variables relating to Impact on members of SHG as Peripheral or Core issue wherein the means are not 
equal from the Descriptive Statistics as shown in Figure 2.

The overall score on the opinion of different stakeholders on whether the aspects like impact on members of SHG and its involvement in larger social issues should be peripheral or core components of quality indicators of SHG is interpreted with the help of Mean of Total Score on IMPC i.e. 22.98. From this mean value, it is observed that different stakeholders believed that the impact on members of SHG and its involvement in larger social issues should be 'somewhat core component' as the mean value (22.98) lies in between the scale range of $1 \& 0$ which represents the zone of "somewhat core component".

From the descriptive statistics on overall score on statements on impact on member of SHG \& involvement in social issues, it is observed that the mean score is almost equal or higher than the mean of overall score i.e. in case of Promoter (21.794), Donor (33.20) and Group member (23.068). It is further observed that the mean on impact on member of SHG \& involvement in social issues in case of Donor (33.20) is too higher than the mean of overall score (22.98) and the mean on impact on member of SHG \& involvement in social issues in case of Financial Institutions (17.50) is too lower than the mean of overall score (22.98). This implies that Financial Institutions are less concerned with the statements on impact on members in social sphere while Donor's are more concerned with the impact on member's social issues.

Table 6. ANOVA on perception of stakeholders of SHG on IMPC

\begin{tabular}{lccccc}
\hline $\begin{array}{l}\text { Overall Score } \\
\text { on IMPC }\end{array}$ & \multicolumn{2}{l}{ Sum of Squares df } & $\begin{array}{l}\text { Mean } \\
\text { Square }\end{array}$ & F & Sig. \\
\hline $\begin{array}{l}\text { Between } \\
\text { Groups }\end{array}$ & 1453.006 & 3 & 484.335 & 2.572 & .059 \\
Within Groups 18078.954 & 96 & 188.322 & & \\
Total & 19531.960 & 99 & & & \\
\hline
\end{tabular}

Source: Compiled from the Questionnaire

Further, from the descriptive analysis on perceived opinion by the different stakeholders on individual statement on impact on member of SHG \& involvement in social, it is observed that out of 65 elements, only on 46 elements where different stakeholders perceived their opinion that these statements relating to impact on members on social perspectives are seems to be a core component while assessing the quality parameters of SHGs. Similarly, out of 65 elements, only on 17 statements they showed their negative perceptions i.e. considered to be peripheral components and on 2 statements they showed their normative approach i.e. neither core nor peripheral component while assessing the quality parameters of SHGs (Figure 2).

\section{Conclusion}

Microfinance institutions target the poor, with the aim of socially and economically empowering them. Donors make the funds available, while the MFIs facilitate their distribution and recovery. The donors, MFI staff and national and regional governments need and want to know how well the program is performing. Program evaluation by means of impact assessment studies provides the requisite information that provides vital feedback to make critical future decisions. Social impact assessment, in contrast to economic assessment, is still in its infancy. As research expands, the discipline will develop and more refined models will facilitate understanding of this multifarious area. To access the perceptions of different stakeholder's viz. Promoters, Donors, Financial institutions and Group members of SHG whether the aspects like impact on members of SHG and its involvement in larger social issues should be peripheral or core components of quality indicators of SHG, Sixty Five (65) statements related to impact on SHG and involvement in social issues are collected and corresponding opinion are quantified with the five point scale as defined in the research methodology.

From the median value on the overall score on the opinion of different stakeholders on whether the aspects like impact on members of SHG and its involvement in larger social issues should be peripheral or core components of quality indicators of SHG it is observed that different stakeholders believed that the impact on members of SHG and its involvement in larger social issues should be 'Somewhat core component' as the mean value (22.98) lies in between the scale range of $1 \& 0$ which represents the zone of "somewhat core component" under given methodology. Further, it is observed that there was no significant effect of Stakeholders on overall score on Impact on members of SHG as Peripheral or Core issue. Finally, this implies that Financial Institutions are less concerned with the statements on impact on members in social sphere while Donor's are more concerned with the impact on member's social issues.

\section{References}

[1] Abdulla, V. K. (2000), "Tribal custom that helps Rural Development", Social Welfare, 47 (5), pp. 20-22.

[2] Adams, D. \& Von Pischke, J. D. (1992), "Micro-enterprise credit programs", World Development, 20(10), pp. 14631470.

[3] Affrane, S. (1998), "Impact Evaluation of Soweto Microenterprise Development Project (SOMED)", Mid-term review report prepared for Australian Agency for International Development (AusAID) and SEED Foundation, South Africa. [Online]. Available: http://msmitwiki.byu.edu/esrreview/articles/article55.pdf. [Accessed February 15, 2010].

[4] Afrane, Sam (2002), "Impact Assessment of Microfinance Interventions in Ghana and South Africa: A Synthesis of Major Impacts and Lessons", Journal of Microfinance / ESR Review, 4(1), pp. 37-58. [Online]. Available:http://ojs.lib.byu.edu/spc/index.php/ESR/article/vi ewFile/1430/1391. [Accessed February 4, 2013]. 
[5] Agricultural Finance Corporation (2005), "Report on Impact Evaluation of Swashakti, MWCD", Agricultural Finance Corporation Ltd, New Delhi.

[6] Ahmed, H. (1999), "Operating formate of micro finance scene: negative shocks and poverty", Savings and Development, L (23), pp. 57-66.

[7] Alreck, P. L., \& Settle, R. B. (1995), The survey research handbook (2nd ed.). Boston, MA: Irwin McGraw-Hill.

[8] Amin, Sajeda, Ashok S. Rai, and Giorgio, Topa (2003), "Does micro credit reach the poor and vulnerable? Evidence from Northern Bangladesh", Journal of Development Economics, 54 (I), pp. 59-82.

[9] Anand, J. S. (2002), "Self-help groups in empowering women: Case study of selected SHGs and NHGs", Discussion Paper 38. Kerala research programme on local level development, Centre for Development Studies, Thiruvananthapuram.

[10] Antia, N. H. and Kadekodi, G. K. (2002), "Dynamics of Rural Development: Lessons from Ralegaon Siddhi”, A Joint Study by the Foundation for Research in Community Health, Pune and Centre for Multi-disciplinary Development Research, Dharwad, pp. 53-56.

[11] APMAS (2009), "Quality and Sustainability of SHGs in Assam". [Online]. Available: http://www.apmas.org/pdf\%5CAssam\%20SHG\%20study\% 20report-\%20final\%2003 0909. pdf. [Accessed October 15, 2013].

[12] Armendariz de Aghion B. \& Morduch, J. (2005), The economics of microfinance, MIT Press, Cambridge.

[13] Armendariz de Aghion B. \& Morduch, J. (2010), The economics of microfinance, (2nd ed.), MIT Press, Cambridge.

[14] Aruna, M. \& Jyothirmayi, R. (2011), "The role of microfinance in women empowerment: A study on bank linkage Program in Hyderabad, Andhra Pradesh", Indian Journal of Commerce and Management Studies, 2(4), pp. $77-95$.

[15] Barnes, C. \& Keogh, E. (1999), "An assessment of the impact of Zambuko's micro-enterprise program in Zimbabwe: Baseline findings", Management Systems International, Washington DC.

[16] Barnes, Carolyn (1996), "Assets and the Impact of Microenterprise Finance Programmes", Management Systems International, Washington DC.

[17] Baruah, Prasenjit Bujar (2009), "Self Help Group and Asset Creation: A Case Study of Deharkuchi Gaon Panchayat of Nalbari District, Assam", The microFINANCE Review, January-June, 1 (1), pp. 183-197.

[18] Bateman, M. \& Chang, H. (2009), "The microfinance illusion". [Online]. Available: http://www.econ.cam.ac.uk/faculty/chang/pubs/Microfinanc e.pdf. [Accessed February 15, 2010].

[19] Beck, T, Demirguc-Kunt, A. \& Levine, R. (2004), "Finance, inequality and poverty: Cross-country evidence", World Bank Policy Research Working Paper 3338, World Bank, Washington DC.
[20] Bera, Sudhin Kumar (2011), "A Study of SHG-Micro finance Initiative in Purbo Midnapore District of West Bengal”, Economic Affairs, 56(2), pp. 107-116.

[21] Bokil, Milind (2005), "Ending domestic violence: self help groups can help", Development Support Team 32, Pune. [Online]. Available: http://nipccd.nic.in/reports/rawe.pdf. [Accessed on 6/09/2012]

[22] Borbora, S. and Mahanta, R. (2008), "Micro finance through Self Help Groups and its Impact: A Case of Rashtriya Grameen Vikas Nidhi-Credit and Saving Programme in Assam", Indian Journal of Agriculture Economic, JulySeptember, 56(3), pp. 449-454.

[23] Brau, J. C. \& Woller, G. M. (2004), "Microfinance: A comprehensive review of the existing literature", Journal of Entrepreneurial Finance and Business Ventures, 9(1), pp. 126.

[24] Buckley, G. (1997), "Microfinance in Africa: Is it either the problem or the solution"? World Development, 25, pp. 1081-1093.

[25] Burra Neera, Ranadive, J. (2005), "Micro Credit, Poverty and Empowerment", in Deshmukh, Joy and Murthy, Rajani K. (Ed.), Micro Credit, Poverty and Empowerment (pp. 3456), Sage Publication Pvt. Ltd, New Delhi.

[26] CERISE Report (2000), CERISE Report. [Online]. Available: http://www.uneca.org [Accessed on 21/02/2010].

[27] Chakrabarti, Rajsh (2004), "The India Microfinance Experience - Accomplishments and Challenges", in Bibek Debroy and Amir Ullah Khan (Eds.), Integrating the Rural Poor into Markets (pp. 32-67), Academic Foundation, New Delhi.

[28] Chandra, Subhash W. (1999), "Sustainable micro credit model for poverty alleviation and empowerment", Financing Agriculture Special Millennium Issue, 31 (3), pp. 84-111.

[29] Chavan, P. \& Birajdar, B. (2009), "Micro finance and financial inclusion of women: An evaluation, Reserve Bank of India Occasional Papers, 30(2), pp. 109-129.

[30] Chavan, P. and Ramakumar, R. (2002), "Micro credit and rural poverty", Economic \& Political Weekly, 37 (10), pp. 955-965

[31] Choudhury, Sanghamitra (2008), "Women Self Help Groups in Empowering Women in a Conflict Situation: in Nalbari (Assam)", Dialogue, 9 (3). [Online]. Available: http://www.asthabharati.org/Dia_Jan08/choud.htm. [Accessed on 22/01/2012]

[32] Copestake, J. (2002), "Inequality and the polarising impact of microcredit: Evidence from Zambia's copper belt", Journal of International Development, 14(6), pp. 743-755.

[33] Copestake, J., Bhalotra, S. \& Johnson, S. (2001), "Assessing the impact of micro-credit: a Zambian case study", Journal of Development Studies, 37(4), pp. 81-100.

[34] Cronbach, L. J. (1951), "Coefficient alpha and the internal structure of tests”, Psychometrika, 16(3), pp. 297-334

[35] De, S. and D. Sarker (2010), "Impact of Micro-credit Programmes on Women Empowerment: An Empirical Study in West Bengal", The Microfinance Review, II (1), pp. 4667. 
[36] Deininger, Klaus \& Liu, Yanyan (2009), "Longer-Term Economic Impacts of Self Help Groups in India", World Bank Policy Research Working Paper 4886, The World Bank Development Research Group Sustainable Rural and Urban Development Team. [Online]. Available: doi: 10.1596/1813-9450-4886. [Accessed on 6/09/2010]

[37] Dhanya, M. B and P. Sivakumar (2010), "Microfinance, Women Empowerment and Banking Habit: Perspective on Kerala", The Microfinance Review, II (1), pp. 97-109.

[38] EDA Rural Systems (2006), "Quality Issues of Self Help Groups in Rajasthan", Centre for Microfinance, Hyderabad. [Online]. Available: http:// www.edarural.com. [Accessed on $6 / 02 / 2010]$

[39] EDA Rural Systems and APMAS (2006), "The Light and Shades of SHGs in India", CRS, USAID, CARE and GTZ/NABARD, CARE India.

[40] Gaddis, S. E. (1998), "How to design online surveys"? Training and Development Journal, 52(6), pp. 67-71.

[41] Gaiha, R. and Mani Arul, N. (2007), "Micro finance, Self Help Groups and Empowerment in Maharashtra", Working Paper 2007/15, Australia South Asia Research Centre, Australian National University, Canberra. [Online]. Available:

http://www.crawford.anu.edu.au/acde/asarc/pdf/papers/2007 /WP2007_15. [Accessed on 6/09/2012]

[42] Gaile, G. L. \& Foster, J. (1996), "Review of methodological approaches to the study of the impact of microenterprise credit programmes", Report submitted to USAID assessing the impact of microenterprise Services (AIMS), June. Cited in Duvendack, Maren (2010). Smoke and Mirrors: Evidence of Microfinance Impact from an Evaluation of SEWA Bank in India. [Online]. Available: http://mpra.ub.unimuenchen.de/id/eprint/24511. [Accessed on 2/12/2012].

[43] Gaonkar, Rekha R. (2001), "Working and Impact of Self Help Groups in Goa", Indian Journal of Agricultural Economics, 56(3), pp. 471-476.

[44] George, D., \& Mallery, P. (2003), SPSS for Windows step by step: A simple guide and reference. 11.0 update (4th ed.), Allyn \& Bacon, Boston, pp. 231.

[45] Ghalib, Asad Kamran (2009), "Measuring the impact of microfinance intervention: A Conceptual framework of social impact assessment", Impact Assessment Research (IARC), University of Manchester, IARC Working Papers Series, No. 24/2009. [Online]. Available: http://www.sed.manchester.ac.uk/research/iarc/publications/ working_papers/. [Accessed February 15, 2013].

[46] Glasson, J. (2000), "Socio-economic impacts: overview and economic impacts" in Morris, P. and Therivel, R. (2000) (Ed.), Methods of Environmental Impact Assessment, Spon Press, London and New York.

[47] Goetz, A. M. \& SenGupta, R. (1996), "Who takes the credit? Gender, power and control over loan use in rural credit programmes in Bangladesh", World Development, 24(1), pp. $45-63$.

[48] Goldberg, N. (2005), "Measuring the impact of micro finance: Taking stock of what we know", Grameen Foundation USA Publication Series, December. [Online]. Available: http://www.givewell.org/.../Independent\%20research\%20on \%20microfinance. [Accessed on 2/12/2012].

[49] Hashemi, S. M., Schuler, S. R. and Riley, A. P. (1996), "Rural Credit Programmes and Women's Empowerment in Bangladesh”, World Development, 24(4), pp. 635-654.

[50] Hietalahti, J. \& Linden, M. (2006), "Socio-economic impacts of microfinance and repayment performance: A case study of the Small Enterprise Foundation, South Africa", Progress in Development Studies, 6(3), pp. 201-210.

[51] Hossain, F. \& Knight. T. (2008), "Financing the poor: can micro-credit make a difference? Empirical observations from Bangladesh", BWPI Working Paper 38. Brooks World Poverty Institute, Manchester.

[52] Hulme, D. \& Mosley, P. (Ed.). (1996), Finance against the poor (Vol. 1 and 2). Routledge, London.

[53] Hulme, D. (2000), "Impact assessment methodologies for microfinance: theory, experience and better practice", World Development, 28(1), pp. 79-88.

[54] Hulme, D. (2003), "Is micro finance good for the poor people? A note on the dark side of micro finance", in Malcom Harper (Ed.), Micro Finance: evolution, Achievements and Challenges. ITDH Publications, London.

[55] Human Development Report (2006), "Human Development Report", published by the United Nations Development Programme (UNDP). [Online]. Available: http://www.undp.org, [Accessed on 21/02/2009].

[56] Husain, Z., Mukherjee, D. \& Dutta, M. (2010), "Self Help Groups and Empowerment of Women: Self Selection or actual benefits"? Munich Personal RePEc Archive No. 20765. [Online]. Available: http://www.mpra.ub.unimuenchen.de/20765/1/MPRA_paper_20765.pdf. [Accessed February 15, 2013].

[57] Hussain, A. M. (1998), "Poverty Alleviation and Empowerment: The Second Impact Assessment Study of BRAC's", Rural Development Programme. BRAC, Dhaka.

[58] IARC (2009), "Impact Assessment Research", University of Manchester, IARC Working Papers Series, No. 24/2009. [Online].

Available: http://www.sed.manchester.ac.uk/research/iarc/publications/ working_papers/. [Accessed February 15, 2013].

[59] IFAD (2003), "Transforming Rural Institutions in order to Reach the Millennium Development Goals", International Fund for Agricultural Development (IFAD). [Online]. Available: http://www.ifad.org/gbdocs/gc/26/e/rural.pdf. [Accessed February 15, 2013].

[60] Jahan, R., Kelkar, G. and Nathan, D. (2004), "Redefining Women's Samman: Micro credit and Gender Relations in Rural Bangladesh", Economic and Political Weekly, 39(32), pp. 3627-3640.

[61] Jain, P. and Moore, Mick (2002), "What makes micro credit programmes effective? Fashionable fallacies and workable realities", IDS Working Paper No.177, Institute of Development Studies, Sussex. [Online]. Available: http://www.ids.ac.uk/publications. [Accessed February 15, 2013].

[62] Jain, Sanjay and Mansuri, Ghazala (2003), "A little at a time: the use of regularly scheduled repayments in microfinance programs", Journal of Development Economics, 72 (2003), 
pp. $\quad$ 253-279. Available: www.elsevier.com/locate/econbase. [Accessed on $2 / 12 / 2012]$

[63] Jose Augusto Tomo Pisco (2001). Social Evaluation of the Micro Finance Institutions in Mozambique. [Online]. Available: http://www.uneca.org [Accessed on 21/02/2010].

[64] Kabeer, N. (1998), "Money can't buy me love? Reevaluating gender, credit and empowerment in rural Bangladesh", IDS Discussion Paper No. 363, Institute of Development Studies, University of Sussex, Brighton.

[65] Kabeer, N. (2001), "Conflicts over credit: re-evaluating the empowerment potential of loans to women in rural Bangladesh", World Development, 29(1), pp. 63-84.

[66] Kabeer, N. (2003), “Assessing the 'wider' social impacts of microfinance services: concepts, methods, findings", IDS Bulletin, 34(4), pp. 106-114.

[67] Karnani, A. (2007), "Microfinance misses its mark", Stanford Social Innovation Review. [Online]. Available: $\mathrm{http}: / /$ nbis.org/nbisresources/sustainable_development_equit $\mathrm{y} /$ microfinance misses its mark_kamani.pdf. [Accessed February 15,2013$]$.

[68] Kashyap, S. K. and S. S. Kashyap (2010), "Impact of BankSHG Linkage Programme in Empowering Rural Women in Nalbari District of Assam: A Case Study", The Microfinance Review, II (1), pp. 68-82.

[69] Kazmin, A. (2010), Micro finance: small loan, big snag. Financial Times, $1^{\text {st }}$ December, 15. [Online]. Available: http://www.ft.com. [Accessed on 23/02/2012].

[70] Khandker, S. (2001, February), "Does micro-finance really benefit the poor? Evidence from Bangladesh", paper Presented at Asia and Pacific Forum on Poverty: Reforming Policies and Institutions for Poverty Reduction on 5th to 9th at Washington DC.

[71] Kumar, A. (2009), "Self Help Groups, Women's Health and Empowerment: Global Thinking and Contextual Issues", Jharkhand Journal of Development and Management Studies, 4(3), pp. 2061-2079.

[72] Kumar, D. Suresh (2009), "Participation in Self-help Group Activities and its Impacts: Evidence from South India", The Bangladesh Development Studies, September XXXII (3), pp 1-18. [Online]. Available: http://www.bids-bd.org/bds/323/BDS_ 32_3\%20Suresh\%20Kumar.pdf. [Accessed February 15, 2013].

[73] Kumar, S. (2010), "Performance and Impact of Self-Help Groups in Punjab - Past Experience and the Roadmap Ahead", The Microfinance Review, II (1), pp. 19-35.

[74] Leedy, P. D., \& Armrod, J. E. (2001), Practical research (7th ed.). Upper Saddle River, Prentice-Hall, NJ.

[75] Lipton, M. (1996), "Successes in anti-poverty. Geneva: International Institute of Labour Studies". [Online]. Available:

http://www.ilo.int/wcmsp5/groups/public/@ed_emp/.../wcm s_123434.pdf. [Accessed February 15, 2013].

[76] Long, L. (1998), Surveys from start to finish. Alexandria, American Society for Training and Development, VA.

[77] Maheswaranathan, S. \& Kennedy, F. B. (2010), "Impact of
Micro-Credit Programmes on Eliminating Economic Hardship of Women", ICBI, University of Kelaniya, Sri Lanka. [Online]. Available: http://www.kln.ac.lk/uokr/ICBI2010/7.pdf. [Accessed June $15,2012]$

[78] Makina, D. \& Malobola, L. M. (2004), “Impact assessment of microfinance programmes, including lessons from Khula Enterprise Finance”, Development Southern Africa, 21(5), pp. 799-814.

[79] Maluccio, A. John and Flores, Rafael (2005), "Impact Evaluation of a Conditional Cash Transfer Program: The Nicaraguan Red de Proteccion Social", Research Report No.141, International Food Policy Research Institute, Washington, D.C. [Online]. Available: http://www.ifpri.org/sites/default/files/publications/fcndp18 4.pdf. [Accessed June 15, 2010].

[80] Manimekalai, M. and Rajeswari, G. (2001), "Nature and Performance of Informal Self Help Groups - A Case from Tamilnadu", Indian Journal of Agricultural Economics, 56(3), pp. 453-454.

[81] Mayoux, L. (1999), "Questioning virtuous spirals: microfinance and women's empowerment in Africa", Journal of International Development, 11, pp. 957-984.

[82] Mayoux, Linda (1997), "Impact Assessment and Women's Empowerment in Micro-Finance Programmes: Issues for a Participatory Action and Learning Approach. (mimeo). Washington DC: Consultative Group to Assist the Poorest (CGAP).

[83] Meetei, K. I. (2011, January), "The impact of MF accessibility through group initiative to Rural Women in Manipur-A case study", paper presented in Seminar BIRD in collaboration with IIBM on Micro finance in North East, on $28^{\text {th }}$ and $29^{\text {th }}$ at Guwahati. [Online]. Available: http://www.docstoc.com/docs/125091327/Seminar-on?Microfinance-in-North-East?-organized-by-BIRD-in. [Accessed on 6/01/2012]

[84] Mia, Md. B. (2005), "ICT in Microfinance: A Bangladesh Perspective", in Stuart Mathison (Ed.), Electronic Banking with the Poor Increasing the Outreach and Sustainability of Microfinance through ICT Innovation (pp. 1-10), The Foundation for Development Cooperation, Bangaladesh. [Online]. Available: http://www.intercooperation.ch/finance/download/skwks/2005IctAndMicrofinance.pdf. [Accessed June 15, 2010].

[85] Micro Finance Institutions Ordinance (2010), Micro Finance Institutions Ordinance. [Online]. Available: http://indiamicrofinance.com/download-andhramicrofinance-ordinance-9. [Accessed on 23/02/2012].

[86] Micro-Credit Summit (1997), "The Micro-Credit Summit: Declaration and Plan for Action", Grameen Foundation, Washington, DC.

[87] Mohindra, K. S. et al. (2008), "Can Micro credit Help Improve the Health of Poor Women? Some Findings from a Cross- Sectional Study in Kerala, India”, International Journal of Equity in Health, 7, 2. [Online]. Available: http://www.equityhealthj.com/content/7/1/2. [Accessed on 26/04/2010]

[88] Montgomery, H \& Weiss, J. (2003), "Great Expectations: Microfinance and Poverty Reduction in Asia and Latin 
America”, ADB Institute Research Paper No.63, ADB, Manila.

[89] Montgomery, R. (1996), "Disciplining or protecting the poor? Avoiding the social costs of peer pressure in micro-credit schemes", Journal of International Development, 8(2), pp. 289-305.

[90] Montgomery, R. Davies, R, Saxena, N C and Ashley, S (1996), "Credit for the poor in Bangladesh: the BRAC Rural Development Programme", in David Hulme and Mosley (Eds.), Finance against Poverty. Routledge, London.

[91] Morduch, J. (1998), "Does microfinance really help the poor? Evidence from flagship programs in Bangladesh", World Bank, Washington DC. [Online]. Available: http://www.worldbank.org/wbp/impact/practice/annex1_2.p df. [Accessed June 15, 2010].

[92] Morduch, J. (2000), "The Microfinance Schism", World Development, 28(4), pp. 617-629.

[93] Mosley, P. \& Hulme, D. (1998), "Microenterprise finance: is there a conflict between growth and poverty alleviation"? World Development, 26, pp. 783-790.

[94] Moyle, T., M. Dollar, and Biswas, S. N. (2006), "Personal and Economic empowerment in Rural Indian women: A Self-help Group Approach", International Journal of Rural Management, 2(2), pp. 245-266.

[95] Mugenda, Olive M. (2003), "Research Methods: Quantitative \& Qualitative Approaches", African Centre for Technology Studies Press, Nairobi, pp. 256.

[96] Mukerjee, Tuhin (2006), "Impact assessment study of SGSY programme on empowerment of women at Babpur village", Vidyasagar School of Social Work, Kolkata, pp. 83.

[97] MYRADA (2002), "Impact of Self Help Groups (Group Processes) on the Social/ Empowerment Status of Women Members in Southern India", Microcredit Innovations Department, National Bank for Agriculture and Rural Development, Mumbai. [Online]. Available: http://www.nabard.org/pdf/publications/sudy_reports/myrad a.pdf. [Accessed on 7/05/2012]

[98] Nair, Ajai (2005), "Sustainability of Microfinance Self Help Groups in India: Would Federating Help"? World Bank Research Working Paper, 3516, February. [Online]. Available:

http://elibrary.worldbank.org/doi/book/10.1596/1813-94503516[Accessed March 1, 2010].

[99] Nath Sarmah, Gunindra \& Das, Diganta Kumar (2012), "Micro Finance, Self Help Groups (SHGS) \& the Socioeconomic Development of Rural People (A Case Study with Special Reference to the Lakhimpur District of Assam)", Asian Journal of Research in Business Economics and Management, 2(4), pp. 145-149.

[100] NCAER (2008), "Impact and Sustainability of SHG-Bank Linkage Programme", National Council of Applied Economic Research New Delhi. [Online]. Available: http://.www.apmas.org/pdf\%5CGTZ_NCAER.pdf. [Accessed June 15, 2010].

[101] Neubert, S. (2000), "Social Impact Analysis of Poverty Alleviation Programmes and Projects - A Contribution to the Debate on the Methodology of Evaluation in Development Cooperation", Frank Cass Publishers in association with the
German Development Institute, Berlin. [Online]. Available: http://www.worldbank.org/ socialanalysissourcebook/SAEvolutionMay2902.pdf. [Accessed February 15, 2010].

[102] Nidheesh, K. B. (2009), "Study on the changing process of Kerala women through Kudumbasree, Kerala", International NGO Journal, 4(8), pp. 352-361.

[103] Nunnally, J. C. and Bernstein, I. H. (1994), Psychometric Theory (3rd ed.).: New York, McGraw-Hill

[104] Odell, K. (2010), "Measuring the impact of micro finance: Taking another look", Grameen Foundation USA Publication Series, May. [Online]. Available: http://business.dom.edu/sites/default/files/documents/Measu ring-the-Impact.pdf. [Accessed on 2/12/2012].

[105] Orso, C. E. (2011), "Microcredit and poverty. An overview of the principal statistical methods used to measure the programme net impacts", POLIS Working Paper No. 180, February. [Online]. Available: http://polis.unipmn.it/pubbl/RePEc/uca/ucapdv/orso180.pdf. [Accessed on 2/12/2012].

[106] Parida, P. C. \& Sinha, Anushree (2010), "Performance and Sustainability of Self Help Groups in India: A Gender Perspective", Asian Development Review, 27 (1), pp. 80 103. [Online]. Available: http://econpapers.repec.org/article/risadbadr/2713.htm. [Accessed on 7/05/2012]

[107] Premchander, S. \& Vanguri, P. (2007), "Micro Finance \& Women's Empowerment: Programme \& Policy Review", CARE, New Delhi. Also cited in Singh, Awadhesh Kumar (2007), "Functioning \& Performance of Swashakti and Swayamsiddha Projects in India”, Planning Commission, Government of India, New Delhi.

[108] Premchander, Smita and Prameela, V. (2007), "Empowering Women through Microfinance: A Policy and Programme Review", Care India, Delhi. [Online]. Available: http://www.careindia.org/ManagePublications. [Accessed on 22/02/2009]

[109] Puhazhendhi, V. and Satyasai, K. J. S. (2000), "Micro Finance for Rural People: An impact evaluation', Microcredit Innovations Department, National Bank for Agriculture and Rural Development, Mumbai.

[110] Puhazhendi, V. and K. C. Badatya (2002, November), "SHG-Bank Linkage Programme for Rural Poor- An Impact Assessment", paper presented at seminar on SBLP at New Delhi on 25th and 26th. Mumbai: NABARD.

[111] Purushotham, P. (2004), "Marketing Support to the SHGs", Kurukshetra, 52 (4), pp. 23-28.

[112] Raghavendra, T. S. (2001), "Performance Evaluation of Self Help Groups: A Case Study of Three Groups in Shimoga District", Indian Journal of Agricultural Economics, 56(3), pp. 466-467.

[113] Rahman, A. (1998), “A micro-credit initiative for equitable and sustainable development: Who pays"? World Development, 26(1), pp. 67-82.

[114] Rahman, Aminur (1999), "Micro credit initiatives for equitable and sustainable development: who pays"? World Development, 27 (1), pp. 39-62. 
[115] Rahman, H. (1995), "Mora Kartik: Seasonal deficits and the vulnerability of the rural poor", in H. Rahman, \& M. Hossain (Eds.), Rethinking rural poverty Bangladesh as a case study (pp. 54-67), University Press Limited, Dhaka.

[116] Ramesh S. Arunachalam, (2011), The Journey of Indian Micro-Finance: Lessons for the Future. Aapti Publications, Chennai. [Online]. Available: http://governancexborders.com/category/andhra-pradeshmicrofinance-crisis. [Accessed March 1, 2012].

[117] Reddy, C. S. (2010), "Will the Indian SHG movement withstand the competition offered by MFIs? CGAP blog on $2^{\text {nd }} \quad$ December". [Online]. Available: http://www.cgap.org/blog/will-indian-shg-movementwithstand-competition-mfis. [Accessed on 23/02/2012].

[118] Reddy, K. Raja \& C. S. Reddy (2012), "Self Help Groups in India: A Study on Quality and Sustainability", ENABLE Publication. [Online]. Available: http://www.enableindia.net. [Accessed on 22/02/2009]

[119] Rogaly, B. (1996), "Micro-finance evangelism, destitute women and the hard selling of a new anti-poverty formula", Development in Practice, 6(2), pp. 100-112.

[120] Rutherford, S. (1996), A critical typology of financial services for the poor, ActionAid and Oxfam, London

[121] Sachidananda \& Kumar (2006), "Micro finance on women's empowerment", The Eastern Anthropologist, 59, pp. 1.

[122] Sa-dhan (2003), "Quality Parameters of SHGs: A Discussion Paper, Discussion Series 2", August. [Online]. Available: http://www.sa-dhan.org. [Accessed February 15, 2009].

[123] Salomo, Wolfgang, G. Bhaskara Rao and N. Naveen Kumar (2010), "A Study of SHG Federation Structures in India: Core Elements for Achieving Sustainability - A Practical Guideline", DGRV, Bonn, and APMAS, Hyderabad.

[124] Samanta, G. (2009), "Microfinance and Women: Gender Issues of Poverty Alleviation and Empowerment", The microfinance REVIEW, January - June, 1(1), pp. 100-120.

[125] Sarkar, Samir \& Baishya, Swati (2012), "Impact of Micro finance in Women Empowerment of Assam: An Impact study of SHGs in Assam", BARNOLIPI - An Interdisciplinary Journal, I (V), pp. 46-69. [Online]. Available: http://www.reflectionedu.com/barnolipi.php. [Accessed on 6/01/2013]

[126] Schuler, S. R. and Hashemi, S. M. (1996), "Credit Programmes, Women's Empowerment and Contraceptive Use in Rural Bangladesh", Studies in Family Planning 25(2), pp. 65-76.

[127] Schuler, S. R., Hashemi, S. M. \& Riley, A. P. (1997), “The influence of women's changing roles and status in Bangladesh's fertility transition: Evidence from a study of credit programs and contraceptive use", World Development, 25(4), pp. 563-576.

[128] Sebstad, J. \& Chen, G. (1996), "Overview of studies on the impact of microenterprise credit. Report submitted to USAID assessing the impact of microenterprise services (AIMS), June", cited in Duvendack, Maren (2010), "Smoke and Mirrors: Evidence of Microfinance Impact from an Evaluation of SEWA Bank in India". [Online]. Available: http://mpra.ub.uni-muenchen.de/id/eprint/24511. [Accessed on $2 / 12 / 2012]$.
[129] Singh, Jai Pal (2006), "PEDO's SHG Programme Impact Assessment, A Draft Report", Centre for Microfinance, Jaipur. [Online]. Available: http://www.solutionexchangeun.net.in/mf. [Accessed on 6/09/2010]

[130] Sinha, F. and Sinha, S. (2002), "Sustainability and Development: Evaluating the Performance of Indian Microfinance", in Beyond Micro credit: Putting Development Back into Microfinance (pp. 264-298), Vistar Publishers, New Delhi.

[131] Snodgrass Donald R. and Sebstab, Jennefer (2002), "Clients in context: The impacts of micro fiancé in three countries", USAID, Office of micro Enterprise Development.

[132] Soroushmehr, Homa, Khalil Kalantari \& Hossein Shabanali Fami (2012), "Investigation of Self help Groups Effect on Rural Women Empowerment (Hamedan County, Iran)", Journal of Agricultural Science, 4(1), 1-11. [Online]. Available: http://www.ccsenet.org/jas. [Accessed on 2/01/2013]

[133] Stewart R., Van Rooyen C., Dickson K., Majoro M., \& De Wet T. (2010), "What is the impact of micro finance on poor people? A systematic review of evidence from sub-Saharan Africa", Technical report, EPPI-Centre, Social Science Research Unit, London. University of Londons, UK. [Online]. Available: http://r4d.dfid.gov.uk/PDF/Outputs/SystematicReviews/Mic roFinance FOR + WEB $\% 5$ B $1 \% 5$ D.pdf. [Accessed on 23/03/2009].

[134] Stewart R., van Rooyen C., Korth M., Chereni A., \& Rebelo Da Silva N., de Wet T. (2012), "Do micro-credit, microsavings and micro-leasing serve as effective financial inclusion interventions enabling poor people, and especially women, to engage in meaningful economic opportunities in low- and middle-income countries: A systematic review of the evidence"? EPPI-Centre, Social Science Research Unit, Institute of Education, University of London, London. [Online]. Available: http://www.ioe.ac.uk/100810_protocol_sr_microcredit_ssa final.pdf. [Accessed on 23/03/2009].

[135] Sujatha, K. S. (2011), "Economic empowerment of women and beyond: SHG as an organizational possibility to find Social development spaces", JM International Journal Management Research, 1(5), pp. 317-328.

[136] The Inter-organizational Committee on Guidelines and Principles for Social Impact Assessment (1994), "Guidelines and Principles for Social Impact Assessment", Department of Commerce, National Oceanic and Atmospheric Administration, National Marine Fisheries Service, USA.

[137] Todd, H. (1996), Women at the centre. Grameen Bank borrowers after one decade, Westview Press, New York.

[138] UNICEF (1997), "Give us credit", Division of Evaluation, Policy and Planning, UNICEF, Geneva. Also cited in Stewart, R., Van, Rooyen C., Majoro, M. \& De Wet T. (2010), "What is the impact of microfinance on poor people? A systematic review of evidence from sub-Saharan Africa (Protocol)", EPPI-Centre, Social Science Research Unit, University of London, London.

[139] Woolcock, Michel J. V. (1999), "Learning from the failures in micro finance: what successful cases tell us about how group based programmes work"? American Journal of Sociology, 58 (1), pp. 17-42. 
[140] Wright Gan (2000), Microfinance systems: designing quality financial services for the poor, Zed Books, London.

[141] Yamuna, G. (2007), "Women Empowerment through Self Help Groups in Solamadevi Village:, in V. S. Ganesamurthy (Ed.), India: Economic Empowerment of Women (pp. 4557). New Century Publication, New Delhi.
[142] Zaman, H. (2001), "Assessing the poverty and vulnerability impact of micro-credit in Bangladesh: a case study of BRAC", unpublished background paper for World Development Report 2000/2001. World Bank, Washington DC. 